\title{
Model of Women Participation in Supporting Government Policies Reducing Neonatal Mortality in Kupang District
}

\author{
Maria Margaretha Ulemadja Wedho ${ }^{1}$, Mintje Ratoe Oedjoe² ${ }^{2}$ David B.W. Pandie ${ }^{3}$ \\ ${ }^{1}$ Candidate Doctor-Nusa Cendana University, ${ }^{2}$ Professor-Nusa Cendana University, \\ ${ }^{3}$ Senior Lecturer-Nusa Cendana University
}

\begin{abstract}
Background: Women are the main actors in reducing infant mortality. Objective: To develop suitable models of woman's participation to support government policy reducing infant mortality in Kupang District. Methods: qualitative method was used and 14 informants and 3 triangulations were selected by purposive sampling technique, followed by snowball sampling. Intervewers consists of 5 midwives, 5 cadres, and 3 chiefs of the village. Findings: The degree of women's participations in this study were low. Forms of participations showed that one Timorese has been given birth at home. Most of the East Timorese informants late reported their pregnancy, gave the porridge sun for babies after 6 months. TIHERO model of woman participation has been created in this study. Recommendation: It is expected that Government to open childbirth education class and model of women participacion must be conduct in terms of reducing neonatal and infant mortality rate.
\end{abstract}

Keywords: Women, Policy, Participation, Neonatal and infant mortality

\section{Introduction}

Neonatal, infant and child mortality rate remain the third target of the second goal of the Sustain Development Goals (SDGs) to reduce neonatal mortality by at least 12 Per 1,000 live births and under-five years mortality 25 Per 1,000 live births. There was a decrease in IMR of 22.23 per 1000 live births ${ }^{(1),(2)}$ in Indonesia. However, the target of SDGs for reducing neonatal deaths has not been achieved yet ${ }^{(3)}$ throughout Indonesia especially in NTT Province, despite Governor Regulation No.422009 concerning Revolution of Maternal and Child Health has been launched and implemented. ${ }^{(1)}$

The target of the $\mathrm{MCH}$ revolution was to reduce the infant mortality rate from 62/1000 live births in 2004 to $27 / 1000$ live births in 2013. However, the number of infant deaths still very fluctuated between 1,272-1350 deaths when evaluated in 2015. ${ }^{(4)}$ Government has relaunched the Technical Guidelines for Leap to Decrease

\section{Corresponding author:}

Maria Margaretha Ulemadja Wedho

E-mail: mariamargarethawedho@gmail.com Address: Jl.Piet A. Tallo, Liliba, Oebobo, Kupang, NTT-Indonesia
Infant Mortality in 2015 with the target of reducing the Neonatal Mortality Rate (NMR) 14 per 1000 lives birth, Infant Mortality Rate (IMR) 23 per 1000 lives birth and Under five Mortality Rate 32 per 1000 lives birth at the end of 2015. The results showed that infant mortality rate also fluctuated, there were 1,388 cases in 2015 , 1091 cases from 86,126 in 2016 and 874 cases out of 86,085 live births in 2017. ${ }^{(5)}$ However, the program was not fully successful in reducing infant mortality yet.

$\mathrm{MCH}$ is a topdown policy that should be government and community work together when formulating policies. (6) The involvement of women as the main actors in the event of pregnancy, childbirth and caring for a baby is not yet apparent in the model of MCH Revolution. In fact, the role of mothers in the family on pregnancy, childbirth, postpartum period can be maximized. Bang, et al. ${ }^{(7)}$ stated that neonatal morbidity can be reduced by training mothers to care for neonates at home and providing maternal health education. Therefore, the aim of the study were to identify women's degree of participation, analysis the form of women participation and build the model of women participation in reducing infant mortality in Kupang regency. 


\section{Method}

Qualitative research was used which fenomenolgy study design to explore women's participation in supporting government policies reducing neonatal mortality in Kupang District. This study was conducted in Kupang Regency, Middle Kupang District and West Kupang from January to Mart 2019. The District was choosen because the majority of the Helong Tribe is domiciled in Bolok Village, Batakte Sub-district, East Timorese are domiciled in the Penfui village of East Timor Kupang; and the majority of the Rote tribe domiciled in Mata Air village, Middle Kupang Tengah ${ }^{(8)}$

Participants were selected by using non-random purposive sampling to determine inclusive criteria including childbearing age women whose pregnant, postnatal, breastfeeding period until the infant was one year old; at least has an Elementary School degree, could read and write, and was willing to be an informant. Furthermore, snowball was used to obtain the subject until data saturation have been achieved. Seventeen main informant participated in this study including 3 triangulation. They were 7 Timorese people, 5 Rote tribes, and 5 Helong tribes. There were also 13 interviewees consisted of 3 chiefs village, 5 midwives and 3 health cadres.

Data were collected by interviews and FGDs. Structured interviews was chosen because each informant got the same question that had been prepared previously by the researcher. Interviews were conducted approximately 40-90 minutes and all conversations were recorded on tape. FGD is carried out for 4-5 hours. Data were analyzed using analysis of themes. There were 3 stages of data analysis consisting of: data reduction, display, and drawing conclusions. ${ }^{(9),(10)}$

\section{Findings and Discussion}

\section{Degree of Women's Participation}

Following questions describe community exposure: "Have you ever heard the MCH program? Almost all informants and the village head answered that they were not exposed to information and never heard about policies. Meanwhile, midwives recognize the $\mathrm{MCH}$ Policy from books and the Head of the health center (FGD-March, 13).

....All pregnant women have to give birth in health facilities and be helped by midwives. During counseling we explained that each delivery must be in the health facilities and every pregnant woman must check the ANC regularly at least 4 times (Mrs.E, 03-13/2019).

However, the technical guidelines for the Leap to Reduce Infant Death book launched in July 2015 were not yet known by midwives as well as the main informan and village head. Following is the statement of midwives: "to be honest, Madame, we don't know too much about this book (Mrs.R, 13/03/2019). Documentary evidence supported the midwive statement because the neonatal visit and postpartum columns are not filled by health worker. Meanwhile, Government emphasized that the supply side must visit a neonate three times consist of: 6-48 hours; 3-7 days and 8-28 days after birth. Postpartum visits three times including: 6 hours to 3 days; 8-28 days and 29-42 days after delivery. Satries ${ }^{(11)}$ stated that lack of information from the government to the community illustrated that the communication was poorly built. A ladder of Citizens Participation ${ }^{(12)}$ was used to measure the degree of participation. The result of this study indicated that the level of participation was at a low level namely manipulation and therapy. Informants were used as an objects in the policies that have been set so that the target is achieved.

\section{Form of Participation}

\section{$\underline{1 . \text { Planning }}$}

Prenatal Plan

Most Timorese informants, reported their pregnancies at more than 2-6 months of gestation.

.....”I have only reported five months of pregnancy because I did not plan........from a last birth I want to take family planning injections.....hen I want to inject, my daughter asked me that I had to wait for my period but it did not happen untill 5 months (Ny.PN, 01/29/2019)".

One of the government's policy in the MCH book is that women should report their pregnancy immediately when amenorrhoe. It seems that the results of this study did not support the policies. As a result, people who implement policies behave indifferently and passively because they feel the program do not belong to them. ${ }^{(13)}$

The following questions were asked to get information about maintaining the health of the fetus and the baby: "Did you plan check your health when you got pregnant?" Almost all informants said that they planned to go regularly to health facilities base on midwife's advice which refers to the policies. ${ }^{(1),(5),(14)}$ 
This is contrary to the basic principles of The New Public Service proposed by Denhardt \& Denhardt ${ }^{(6)}$ and Mikkelsen. ${ }^{(15)}$

The focus of attention in the implementation of public policy is the involvement of citizens since identifying problems, planning, implementing until monitoring and evaluating. However, the reality faced is focused at the application of old public administration character where policies are top-down.

\section{Delivery plan}

All informants planned to deliver at the health facilities and were helped by health workers. But there was one Timorese informant who had given birth at home helped by his mother-in-law.

At the beginning the birth was planned to be in the hospital and to get sterilization immediately. But my mother in law came and said that I have to give birth at home and so it happened. The reason is because my mother in law is a shaman so she knows to handle the birth (Mrs.MT, 01/30/2019).

Mother in-law is considered a helper and has power over pregnancy and childbirth in Timorese culture. These results supported the research of Khairunnisa et al. ${ }^{(16)}$ that the role of the family is very important in determining the place of delivery and birth attendance. Form of efforts to accelerate the decline in infant mortality is through delivery at an adequate health facilities and assisted by competent health personnel. (1),(14)

\section{Care plans for babies}

All informants in this study planned to give exclusive breastfeeding for 6 months followed by complementary food such as sun porridge (most Timorese) and cooked, blended porridge mixed with vegetable (Rote and Helong) and immunization.

"Exclusive breastfeeding is 6 months. After that sun porridge was given (Mrs.BD, 28/01/2019)".

This result contradicted with the information contain in the MCH book. ${ }^{(14)}$ Mother is recommended to prioritize the provision of complementary food from local food ingredients. Unfortunately, almost all informan did not read the pink book of $\mathrm{MCH}$, even if they read many terms and procedures that were not understood. ${ }^{(14)}$ They did not get the information either from health workers.
The results of this study did not support the government policies about childbirth education at least 4 times. In this study all informants said that there had been no classes of pregnant women.

\section{Implementation}

\section{Prenatal and breastfeeding period}

All informants said that they would and had put everything they had planned such as checking themself regularly.

After knowing that I had been pregnant, I reported to the Health Centre and got the pink book, then my blood pressure was checked and was given folic acid and vitamin B-complex. Fetal heart rate, my height, and weight, laboratory tests for Hepatitis, HIV AIDS and HBSAg was taken (Mrs.ACT, 01/02/2019).

The form of community participation according to Andreeyan $^{(17)}$ is the form of taking part in working together and donations of money or material, meanwhile Azhar $^{(18)}$ is the ideas forwarded in development planning deliberation forum. Participation were a form of individual, family and a form of public involvement. (19) In this study the forms of participation were part of the community and family members activities during pregnancy, and postnatal phase which are carried out according to plan.

\section{Monitoring and Evaluation during prenatal} and post natal.

Informants in this study said that fetal development and maternal health were checked regularly.

.......Because from the moment I became pregnant, my blood pressure was low so midwife said I had to rest a lot because I was afraid of bleeding during delivery. So I went to the hospital to check blood for Haemoglobin. From the village office, I once got rice, coocking oil, 1 pack of eggs, 510.000 rupees for my baby to buy side dishes. (Mrs.MLS, 01/29/2019).

All informants visited health workers to weighing babies and immunization eventhough the type and benefit of immunization are not understood.

"I gave birth in the morning, and back home in the afternoon. One week later I came to the clinic for immunization and control the baby". 
However, almost all informant did not make neonatal and puerperal visits 1,2,3.(1),(14),(20) eventhough this visit is highly recommended in government policy because the death event occur during this period. ${ }^{(1),(14),(20)}$

Firdaus $^{(21)}$ stated that ways to identify whether activities has been deliver as close as possible to the plan called monitoring. While the assessment of the course of the program is called evaluation. ${ }^{(21)}$ Evaluations and monitors carried out in this study aimed more at monitoring fetal growth and development in the womb and evaluating the health of the mother. Postnatal women was evaluated on maternal health to monitor whether there were problems. For instance, there were a Timor tribe's informant planned to give birth at a health centre but eventually gave birth at Leona Hospital because she got pre-eclampsia since 8 months of gestation.

\section{Women Participation Model Namely TIHERO}

Proposition in this study is that the higher the knowledge of women the higher their participation in supporting government policies to reduce infant mortality. The citizens participation used in this study referred to "The Ladder of Participation Theory. (12) Arnstein $^{(12)}$ introduced 3 degrees of community participation consist of eight ladder of participation including: the highest degree is the power of citizens (control of citizens, delegated power, and partnerships); the second degree with 3 steps (placation, consultation and informing), the lowest degree is non-participation (therapy and manipulation). Overall, Arnstein's level of participation $^{(12)}$ places more emphasis on the power of citizens, being objective conceptions. Arnstein discussed the level of participation structurally without taking into account the subjectivity of the women who participated in this study. Whereas in this study the subjective experience of a woman is more emphasized.

In this study women were not exposed to government policies even though they were experiencing prenatal, natal, and postnatal periods. The advice of health workers to success the government programs is passively accepted, because they have not been involved in the process of problem identification, planning, and policy formulation; and also they have cultural and hereditary values that must be adhered. Therefore women need to be encouraged to get into the public domain so that they can recognize the reality faced in relation to women's reproduction. The public domain is a place where people can express their aspirations as public opinion which can be conveyed to the government for consideration in policy formulation. ${ }^{(22),(23)}$ According to Habermas ${ }^{(22),(23)}$ in the public sphere communication will be created in an open and equal public space from experts, bureaucracies, legislative commissions and the public in the forum. Habermas's view is very objective and structural without taking into account the subjective aspects as in this study. How about the women in this study who were considered as housewives those who were marginalized in development? How can they express their aspirations if they themselves do not know about the topic to be discussed?

The new ladder of participation from TIHERO woman has been proposed in this study based on Arnstein's theory. There were three degree of participation namely ladder of quality information; partnership; and independent in self-maintenance. Women need quality information so that they are aware that they have a great responsibility for the survival of a human child. This awareness will encourage them to learn about all things related to woman reproduction. Then partnership with health workers in gaining knowledge is needed. Women can be involved in the public sphere that is related to their baby's life and health, if they are knowledgable. They can regulate and control all their behavior and attitudes in maintaining themselves and their fetuses. So that the third degree is self-maintenance independently during prenatal, natal or childbirth, and postnatal.

\section{Conclussion}

The degree of participation is low which means that actually the community does not participate. Form of participations including: reported the pregnancy on time although there were several Timorese women who report late, gave sun porridge as complementary food by Timorese; determined to delivery at hospital by health worker eventhough one Timorese has been given birth at home, and took their children to be immunized although the types and benefits of immunization are poorly understood.

Ethical Clearance- Taken from Undana Institutional Review Board

Source of Funding-authors

Conflict of Interest-No

\section{References}

1. NTT-Health-Office. Guidelines for $\mathrm{MCH}$ 
Revolution in NTT Province (Governor Regulation: Implementation Guidelines and Technical Guidance): Acceleration in Decreasing Maternal and Newborn Death. Kupang: NTT-Health-Office; 2012.

2. BPS-RI. SUPAS. Jakarta: BPS-RI; 2015.

3. MoH-RI. This is the Achievement of the Ministry of Health of the Republic of Indonesia in 20152017. Jakarta: MoH-RI; 2017.

4. NTT-Health-Office. F1-F8 Report and Intermediate Indicator Report, $\mathrm{MCH}$ Revolution in NTT, Regency / City Year 2008-2014 through the Public Health Sector, NTT Health Service. Kupang: NTTHealth-Office; 2017.

5. Kupang-Health-Office. Health Profile of Kupang. Kupang: Kupang-Health-Office; 2015.

6. Denhardt VJ, Denhardt DB. The New Public Service: Serving, not Steering, Expanded Edition. England: M.E. Sharpe; 2007.

7. Bang AA, et al. Reduce Incidence of Neonatal Morbidities: Effect of Home-Based Neonatal Care in Rural Gadchiroli India. Journal of Perinatology. 2005;25:SS1-S61.

8. BPS-Kupang. Kupang Regency in Figures. Kupang: BPS-Kupang; 2018.

9. Sugiyono. Quantitative, Qualitative, and R\&D Research Methods. Bandung: Alfabeta; 2014.

10. Creswell WJ. Qualitative Research \& Research Design: Choosing Among the Five Approaches. Yogyakarta: Pustaka-Pelajar-Publisher; 2015.

11. Satries IW. Measuring the Level of Participation of Bekasi City Communities in the Compilation of the Regional Budget through the Implementation of the Musrembang 2010. Jur.Kyberman. 2010;2(2):89129.

12. Arnstein SR. A Ladder of Citizen Participation. Journal of the American Planning Association. 1969;35(4):216-224.
13. Abdus M. Community Participation in the Implementation of the Alert Village in Tumbukan Banyu Village, Daha Selatan District, South Kalimantan Province. Makassar: UNHAS; 2015.

14. MoH-RI. Maternal and Child Book. Jakarta: $\mathrm{MoH}-$ RI; 2016.

15. Mikkelsen B. Research Methods of Participatory and Empowerment Efforts. Jakarta: UI-Press; 2006.

16. Khairunnisa M, Leksani EIN, Lens D, Roosihermiatie. Health Ethnographic Research: Rote Women Going Through Tradition. Jakarta: MoH-RI; 2014.

17. Andreeyan R. Study of Community Participation in the Implementation of Development in Sambutan Village, Sambutan District, Samarinda City. e-Journal.Adm.Neg. 2014;2(4):1938-1951.

18. Azhar F. Community Participation in Development Planning Consultation (MUSRENBANG) in Pegirian Village, Semampir District, Surabaya City. Jur.Keb.Man.Pub. 2015;3(2):63-70.

19. MoH-RI. Health Information for Mass Media Officers. Jakarta: MoH-RI; 1991.

20. NTT-Health Office. Technical Guidelines for the Leap to Reducing Infant Death in NTT Province. Kupang: NTT-Health Office; 2015.

21. Firdaus. Evaluation of Social Development Projects in the Mbeliling Forest Area Community group, West Manggarai Regency, NTT. Jur.Ilm. Sos.Mamangan. 2016:5(1):13-70.

22. Habermas, Jürgen. The Structural Transfomation of Public Sphere: An Inquiry into Category of Beurgeois Society. Thomas Burger (Translator). Cambrigde: MIT-Press; 1989.

23. Rehg W (Translator). Between Facts and Norms: Contribution to a Discourse Theory of Law and Democracy.Cambrige: MIT-Press; 1996. 